УДК 378.015.31:[165.742+140.8]:37-051(091)(045)

DOI:

Наталія Павинська, кандидат педагогічних наук, доцент кафедри соціально-економічних дисииилін, Комунального закладу

“Харківська гуманітарно-педагогічна академія” Харківської обласної ради

\title{
ФОРМУВАННЯ У МАЙБУТНІХ УЧИТЕЛІВ ГУМАНІСТИЧНОГО СВІТОГЛЯДУ У ТВОРЧІЙ СПАДЩИНІ ПЕДАГОГІВ
}

Сочіально-економічні перетворення, що відбуваються сьогодні, зумовили пошук нових світоглядних орієнтирів нашого суспільства. Тому в умовах переоцінки, зміни усталених цінностей як ніколи важливим $\epsilon$ акиентування уваги закладів вищої освіти на підготовиі вчителя, здатного керувати гармонійним розвитком особистості школярів, залучати їх до загальнолюдських ідеалів і духовних изінностей. Суспільством затребуваний вчитель, який виступає активним суб'єктом педагогічного процесу, здатний не тільки до адаптаиії, а й готовий праџювати в нових умовах, що змінюються. У статті проаналізовано проблеми гуманістичного світогляду та розкрито погляди педагогів на формування у майбутніх учителів гуманістичного світогляду. Звернено увагу на творчу спадщину педагогів-гуманістів Ш. Амонашвілі, А. Макаренка, Г. Сковороди, В. Сухомлинського, К. Уиинського.

Ключові слова: гуманізм; світогляд; формування; майбутні вчителі; творча спадщина.

Лim. 5.

Nataliya Pavynska, Ph.D.(Pedagogy), Associate Professor of the Social and Economic Disciplines Department, Municipal Establishment, "Kharkiv Humanitarian and Pedagogical Academy" Kharkiv Regional Council

\section{THE FORMATION OF THE HUMANISTIC OUTLOOK OF THE FUTURE TEACHERS IN THE CREATIVE HERITAGE OF TEACHERS}

The socio-economic changes taking place in the today's environment, led to the search for new ideological orientation of our society. Therefore, in conditions of reassessment, changes of the established values, as never before important, are the emphasis on the attention of higher education institutions to the preparation of a teacher capable to manage the harmonious development of the personality of schoolchildren, involving them into universal human ideals and spiritual values. The society is in demand by the teacher, who acts as an active subject of the pedagogical process, is capable not only to adapt, but also ready to work in new, changeable environment.

However, it should be noted that the teacher in the broad sense - is a thinker, a public figure that shapes the views and beliefs of students, helps them to find their goals and objectives. Awareness of the special role of a teacher in a society due to the specifics of the activity and the ability to influence the development of the student's personality imposes a high ideological responsibility on institutions of higher education.

This intelligence determined that under humanism in everyday life understood kindness, courtesy, kindness, respect for human compassion strange affliction, mutual. In the general sense, humanism is understood as a historically changing system of views, recognizes the value of man as a person, right to freedom, happiness, development and manifestation of abilities, considers the person's benefit a criterion of assessing social institutions, and the principles of equality, justice, humanity, the desired norm of relations between people. Humanism usually acts as a worldview, the main principles of which are love for people, respect human dignity, care of people. In humanism, the aspiration of personality, collective and society of happiness and perfection is embodied.

It is determined that for the formation of a humanistic worldview, the future teachers need love and kindness, creativity and novelty, intuition and wisdom, optimism and patience, courage and devotion, understanding their teacher's grandeur and modesty. It is these human qualities that are revealed in the creativity of the teachers, through which the worldview is shaped by future teachers.

The article analyzes the problems of the humanistic world outlook and reveals the views of teachers on the formation of a humanist outlook from future teachers. Attention is drawn to the creative heritage of humanist educators, such as Sh. Amonashvili, A. Makarenko, G. Skovoroda, V. Sukhomlynskiy, K. Ushinskiy.

Keywords: humanism; world outlook; the formation; the future teachers; creative heritage.

П остановка проблеми у загальному вигляді. Закон України "Про освіту" визначає, що мета освітнього процесу - усебічний розвиток людини як особистості та найвищої цінності суспільства. У національній доктрині “Освіта у XXI столітті” [5] йдеться про необхідність утвердження ідеалів правди, справедливості, патріотизму, доброти, працелюбності та інших доброчинностей.

А сучасний учитель? Яким він має бути 


\section{ФОРМУВАННЯ У МАЙБУТНІХ УЧИТЕЛІВ ГУМАНІСТИЧНОГОСВІТОГЛЯДУ УТВОРЧІЙ СПАДЩИНІ ПЕДАГОГІВ}

сьогодні? Які ідеали йому сповідувати, коли життєва практика ставить під сумнів ідеали гуманізму, віддаючи перевагу силі й спритності? За якими законами він мусить жити й працювати, аби не зрадити ані своєї професійної честі, ані покликання педагога? Томуз новим осмисленням відносин людини і світу пов'язаний пошук шляхів гуманізації освіти, перш за все це стосується підготовки педагога, формування його гуманістичного світогляду. Одним із можливих шляхів творчого вирішення актуальних проблем виховання $€$ звернення до творчої спадщини педагогів.

Аналіз досліджень і публікацій. Видатних мислителів вирізняє особлива гуманістична складова їхніх поглядів. Тому у сучасників активізувався науковий інтерес до педагогічних ідей та виховної системи педагогів. Сучасні дослідники здійснюють вагомий внесок у розвиток національної і світової гуманістичної думки (І. Зязюн, М. Кисельов, В. Ільїн, Н. Поліщук), наголошують на доцільності використання спадщини гуманістів для формування якостей особистості молоді та вчителів (Н. Дига, В. Захарова, В. Коцур, В. Хомич), виокремлюють складові його вчення, які слугують гуманізації сучасних поглядів на виховання й освіту (Л. Горенко-Баранівська, Р. Множинська, Я. Стратій). У розвідках про творчість педагогів, що здійснюються останнім часом, визначається місце і роль виховання (Л. Образцова, Н. Окса, А. Фролов), а також їхнє використання у педагогічній практиці (В. Бучковська, С. Єгорова, Є. Корабльова). Доцільно підкреслити, що питання про місце світоглядної підготовки в системі педагогічної освіти так чи інакше досліджували І. Богданова, С. Болсун, І. Підласий, О. Савченко, С. Трипольська, Л. Хомич та ін. Проте у працях дослідників не представлено комплексний аналіз формування у майбутніх учителів гуманістичного світогляду у творчій спадщині педагогів.

Формулювання цілей статті. Дослідити стан розробленості проблем гуманістичного світогляду та проаналізувати формування у майбутніх учителів гуманістичного світогляду у творчій спадщині педагогів.

Виклад основного матеріалу. На сьогоднішній день проблема гуманізму є актуальною, особливо коли мова йде про педагогів. Гуманістичні ідеї це запорука успіху у спілкуванні між людьми. Під гуманізмом у повсякденному житті розуміється доброзичливість, ввічливість, людяність, повага до людини, співчуття чужому горю, взаємодопомога. У загальному значенні гуманізм розуміється як система поглядів, що історично змінюється визнає цінність людини як особистості, його право на свободу, щастя, розвиток і вияв своїх здібностей, уважає благо людини критерієм оцінки соціальних інститутів, а принципи рівності, справедливості, людяності бажаною нормою відносин між людьми. Гуманізм зазвичай виступає як світогляд, основними принципами якого є любов до людей, повага людської гідності, турбота про людей. У ньому втілюється прагнення особистості, колективу та соціуму до щастя й досконалості.

Як теоретична концепція гуманізм визнає право людини на свободу, щастя, безперешкодний розвиток і вияв своїх здібностей, творчого потенціалу. Ці риси виступають у гуманістичній концепції основними критеріями оцінки в діяльності основних соціальних інститутів, цільових суспільних установок і спрямованості суспільного розвитку. У відносинах між членами суспільства гуманізм визнає норми та принципи рівних можливостей, соціальної справедливості, високу культуру спілкування й людяності [2].

Отже, гуманізм - це новий світогляд, усвідомлення повноти величі людини, ііі здатність зрозуміти і перетворити на благо все багатство і розмаїття довкілля, з яким людина пов'язана нерозривно, оскільки є “вузлом”, центром світу, творцем власного буття.

Тому одним із можливих шляхів творчого вирішення актуальних проблем сучасного виховання є звернення до педагогічної спадщини педагогів.

Зазначимо, що в Україні найвидатнішим продовжувачем ідей гуманізму епохи Відродження у XVIII ст. був Г. Сковорода (1722 - 1794), котрий глибоко осмислив місце людини у світі, сутність людського щастя, сенс буття, шляхи досягнення людиною блаженства в реальному житті, висунув просвітницьку ідею щодо перетворення праці із засобу існування на найпершу життєву потребу і найвищу насолоду (“Басни Харьковськія”, філософські діалоги), відстоював прагнення особи до “спорідненої” праці, яка б відповідала їі нахилам. Уся його літературна й філософська спадщина - то “проповідь життєрадісної гуманності" (І. Франко) [6].

До вчителя мислитель висував великі вимоги: насамперед глибокі знання, відданість своєму народу, гуманність, повагу до тих, кого він навчає, здатність переконливо володіти словом, терплячість, безкорисливість тощо. За Г. Сковородою, успіх у діяльності людини зумовлюється не лише ії̈ здібностями, а й такими 
якостями, як працьовитість, терплячість, уміння володіти собою, поміркованість, доброчесність, справедливість, доброзичливість, вдячність, скромність, бадьорість духу (“кураж”), а також гуманізм та милосердя [3].

На основі цих принципів великого філософа і мислителя Г. Сковороди можна досягти найзаповітнішої мети педагогів - створення гармонійно розвиненої людини.

Гуманізм Г. Сковороди полягав у тому, що основою буття людини виступає друга природа, вічне, нетлінне, душевне, а “внутрішня людина" ним наділялася божественними рисами. Внутрішнє переживання, страждання і радість $\epsilon$ культурним ідеалом філософа. Мислитель відстоював думку про те, що за своєю природою людина не зіпсована, добра, що “справді людське серце і розум аж ніяк не можуть бажати зла людям”. На думку філософа, причинами, що породжують моральні вади, інші відхилення у поведінці, є суспільні умови та неосвіченість [6].

Удосконалення людини філософ-гуманіст пов'язує зі самовдосконаленням, щастям, спорідненою працею, необхідністю пізнання самого себе, повагою до знань, до шанування людей тощо.

Підкреслимо, що у його педагогічних поглядах віддзеркалені основні напрями передової педагогіки: гуманізм, демократизм, висока моральність, любов до Батьківщини і народу. У притчах та байках Григорій Савич висміював бездуховне дворянсько-аристократичне виховання і протиставляв йому позитивний ідеал виховання, мета якого - утвердження високих моральних якостей, формування гармонійно розвинутої особистості [6].

Педагог наголошував, що в кожній людині закладені великі творчі сили, здібності. Завдання педагога полягає передусім у тому, щоб ці здібності розпізнати і відповідно розвинути.

Визначний український філософ і просвітитель Г. Сковорода вважав, що одним із найголовніших обов'язків педагога є виявлення і розвиток природних можливостей вихованця: “Учитель и врач - нєсть врач и учитель, а только служитель природы, единственныя и истинныя и врачебницы, и учительницы”. Тільки щиро люблячи своїх вихованців, гуманно ставлячись до них, педагог може успішно формувати їхнє моральне обличчя, збуджувати й утверджувати в них любов до людей, “... помічати або розуміти; а чим більше хто помічає, тим більше плекає надії, а чим більше плекає надії, тим полум'яніше любить, з радістю творить добро, безмежно і безмірно, наскільки це можливо" [3; 6].
Принцип гуманізму доповнює сформована ідея А. Макаренка. Гуманізм Антона Семеновича базувався на необхідності ставити якнайвищі вимоги до людини, водночас виявляючи більше поваги та вимогливості, вірі та їі можливості; радості, щасті, красоті, турботі, запобігливості $[4,119]$. Основні положення педагогічної теорії А. Макаренка відзначалися глибоким гуманізмом та базувалися на поєднанні поваги та вимогливості, вірі в людину та їі можливості, на принципі виховання в колективі та через колектив. Повага до вихованця - це вміння довіряти людині, бачити позитивні сторони його характеру та поведінки, вміння спиратися на ці якості при вихованні, вірити у безмежні можливості вдосконалення особистості. Навчити людину володіти собою, розумно керувати своїми почуттями та вчинками - було основою новаторської педагогічної діяльності А. Макаренка. Його життєва формула “как можно больше требований к человеку и как можно больше уважения к нему" [4] визначала всі норми взаємовідносин між особистостями у колективі. Вимогливість до кожного члену колективу як з боку педагогів, так і з боку товаришів була націлена виключно на подолання недоліків та стимулювання кращих рис характеру особистості.

У вітчизняній психолого-педагогічній науці радянського періоду мова йшла переважно про загальний розвиток моральних цінностей людини майбутнього. В. Сухомлинський присвятив найбільше праць проблемі формування гуманності, вказував на необхідність виховати людину, для якої найбільшою цінністю була б людська гідність, котра б уміла поважати, цінувати і себе, й інших.

У процесі дослідження виявлено, що В. Сухомлинський сформулював педагогічну концепцію, основою якої є повага і довіра до дитини, визнання ㄲï унікальності та права на власний моральний вибір. У своїй педагогічній практиці він відстоював головну філософськуідею свого життя: гуманне суспільство можуть створювати лише мудрі люди, яких може виховати лише гуманізм. В. Сухомлинський у багатьох своїх працях зазначав, що у виконанні складних завдань навчання і виховання значна роль належить учителеві. Учений глибоко досліджував цю проблему та її особливості. Він стверджував: “...необхідно, щоб особистість вчителя здійснювала найбільш яскравий, діяльнісний і благотворний вплив на особистість учня ...” $[8,449]$.

Виховання людяності, яке, на думку вченого, відбувається через створення добра людям, і 


\section{ФОРМУВАННЯ У МАЙБУТНІХ УЧИТЕЛІВ ГУМАНІСТИЧНОГО СВІТОГЛЯДУ У ТВОРЧІЙ СПАДЩИНІ ПЕДАГОГІВ}

всебічний гармонійний розвиток у педагогічній системі Василя Олександровича ми вбачаємо як двосторонній процес: через створення добра іншим людям людина вдосконалює свої моральні гуманістичні особистісні якості, і навпаки - саме через реалізацію внутрішньої потреби бути чуйною, справедливою, терпимою, тактовною, відповідальною тощо увідношенні до інших людей у людини виховується людяність як найвища мета гуманістичного виховання особистості [7].

Гуманізм педагогічної системи В. Сухомлинського грунтується наположеннях про самоцінність людини, iii право на свободу і гідність як неповторну індивідуальність. Він висунув і розвинув концепцію відносної автономії конкретної особи, іiї право на вибір на основі власної совісті $[7 ; 8]$.

Виховання заради щастя дитини - такий гуманістичний сенс педагогічної діяльності В. Сухомлинського. Першорядне завдання учителя, вважав він, полягає в тому, щоб відкрити в кожній людині творця, поставити іiї на шлях самобутньо-творчої, інтелектуально-повнокровної праці. "Розпізнати, виявити, розкрити, випестити, викохати в кожному учневі його неповторноіндивідуальний талант - значить підняти особистість на високий рівень розквіту людської гідності” [7; 8].

Видатний вітчизняний педагог К. Ушинський заклав теоретичні основи національної гуманної педагогіки. Ідеальний учитель, на його думку, тонко відчуває душевний стан своїх учнів, убачає в них особистості, гідні такої самої поваги та визнання своїх прав, як і дорослі люди. Педагог повинен створювати взаємини, за яких виникає можливість особистісного впливу вчителя, його розуму, моральності, волі, характеру на особистість вихованця [9].

Масова проповідь ідеї гуманної педагогіки кінця XX - початку XXI століття пов'язується 3 ім'ям Ш. Амонашвілі. Не можна навчити тому, чого сам не знаєш. Якщо вчитель не має духовності й моральності, він не зуміє виховати їх в учнях. Педагогіка - міра всіх наук. Усі науки підкоряються педагогіці. Гуманна педагогіка - це педагогіка, за допомогою якої дитина знаходить світло в собі й в оточуючих. Педагогічний процес - це ви, ваш настрій і стан. Людина повинна усвідомити свою долю, свій шлях, свою маленьку, але місію. Причому пошуки веде сама людина, але направити іiі ще в ранньому дитинстві зобов'язаний учитель. Гуманна педагогіка самовіддано допомагати дітям відкрити в собі долю [1].

Відзначимо, що прогностичний характер гуманістичної педагогіки визначає майбутнє людини і $є$ твердженням, що всі зміни, що відбуваються в особистості людини, залежать від його особистісних проявів і активності, які спираються на силу розуму, а не на сферу соціального контакту з суспільством по відношенню до індивіда [5]. Тим самим "Школа життя" стверджує пріоритет свідомості над буттям. У зв' язку з цим гуманізація педагогічного процесу виключає безособистісний підхід до людини.

Гуманістичне спрямування на людину, культуру в соціумі як взаємопов'язані детермінанти педагогічної взаємодії мають підтримувати індивідуальний розвиток і самовизначення людини. Таким чином, постулати гуманістичної педагогіки створили передумови для виникнення особистісно орієнтованих моделей і стратегій майбутнього освіти.

У процесі дослідження привертає увагу той факт, що Ш. Амонашвілі особливо виділяе фундаментальне поняття - “духовний гуманізм”. Тільки через зміну педагогічної свідомості на основі понять духовності, гуманності, любові, добра, миру можна буде подолати “ваду” освіти - авторитаризм з його наслідками множення бездуховності й аморальності в сучасному суспільстві. Авторитарній педагогіці протистоїть гуманна педагогіка, яка на перше місце ставить духовні цінності. Авторитарна ж педагогіка віддає пріоритет матеріальним цінностям і благам, хоча вона теж виховала багато хороших учених [1].

Як зазначає Ш. Амонашвілі, гуманний учитель намагається розкрити свій характер у трьох якостях

Перша якість - доброта. Доброта учителя до учня - це мати доброти серця учня до всього світу.

Друга якість - щирість. Учительська щирість - умова духовного єднання з учнем.

Третя якість - відданість. Відданість учителя примножує в учневі надію на порятунок і дарує йому прихисток.

Висновки. Отже, результати проведеного дослідження дозволяють стверджувати, що гуманізм - це система ідей і поглядів на людину як найвищу цінність, захист її прав, свобод і щастя, створення необхідних умов для всебічного розвитку кожної особистості й найширшого вияву iіi здібностей.

Таким чином, ми бачимо, що у творчій спадщині педагогів закладено такі складові 3 формування гуманістичного світогляду у майбутніх учителів, як справедливість, доброзичливість, вдячність, скромність, милосердя, оптимізм і вимогливість; через створення добра іншим людям, реалізацію 
внутрішньої потреби бути чуйною, терпимою, тактовною та відповідальною, необхідність пізнання самого себе, повагу до знань, до шанування людей тощо.

Перспективи подальших розвідок у даному напрямі пов'язані з висвітленням ролі духовних цінностей у процесі формування у майбутніх учителів гуманістичного світогляду.

\section{ЛІТЕРАТУРА}

1. Амонашвили Ш. А. Основы гуманной педагогики / Шалва Амонашвили. - Москва: Амрита, 2012. - Кн. 3. - 230 с.

2. Бех І. Д. Виховання особистості: Особистісно орієнтований підхід: теоретико-технологічні засади: [наукове видання] / І. Д Бех. - Київ: Либідь, 2003. - 280 с. - (у 2 кн., кн. 1).

3. Левківський М. В. Історія педагогіки: підручник / М. В. Левківський. - Київ: Центр навч. літ-ри, 2003. -360 с.

4. Макаренко А. С. Мои педагогические воззрения / А. С. Макаренко // Педагогические сочинения в 8-ми томах. - Москва: Педагогика, 1984. - Т. 4. - C. 343-364.

5. Національна доктрина розвитку освіти : Указ президента України від 17.04.2002 № 347/2002 [Електронний ресурс]. - Режим доступу: zakon.rada.gov.ua. - Назва з екрану.

6. Сковорода Г. Повне зібрання творів: в 2-х т. - Київ: Наукова думка, 1973. - Т. 1. - 532 с.; Т. 2. $-576 \mathrm{c}$.

7. Сухомлинський В. О. Вибрані твори: у 5 т. / В. О. Сухомлинський. - Т. 5. - Київ: Рад. школа, 1977. $-639 \mathrm{c}$.

8. Сухомлинський В. О. Вибрані твори: у 5 т. / В. О. Сухомлинський. - Т. 2. - Київ: Рад. школа, 1976. -521 с.

9. Ушинский К. Д. Педагогические сочинения в 6 т. / К. Д. Ушинский. - Т. 6. - Педагогика, 1990. $-528 \mathrm{c}$.

\section{REFERENCES}

1. Amonashvili, Sh. A. (2012). Osnovyi gumannoy pedagogiki [Fundamentals of humane pedagogy]. Moskva: Amrita. Kn. 3, 230 p. [in Russian].

2. Bekh, I. D. (2003). Vykhovannia osobystosti: Osobystisno oriientovanyi pidkhid: teoretykotekhnolohichni zasady [Personality upbringing: Personally oriented approach: theoretical and technological principles]. Kyiv: Lybid. 280 p. (u 2 kn., kn. 1). [in Ukrainian].

3. Levkivskyi, M. V (2003). Istoriia pedahohiky [History of pedagogy]. Kyiv: Tsentr navch. lit-ry, 360 p. [in Ukrainian].

4. Makarenko, A. S. (1984). Moi pedagogicheskie vozzreniya [My pedagogical views]. Pedagogicheskie sochineniya v 8-mi tomakh. Moskva: Pedagogika. T. 4. pp. 343-364. [in Russian].

5. Natsionalna doktryna rozvytku osvity [National Doctrine of Education]: Ukaz prezydenta Ukrainy vid 17.04.2002 № 347/2002 [Elektronic resource]. Retrieved from: zakon.rada.gov.ua. [in Ukrainian].

6. Skovoroda, H. (1973). Povne zibrannia tvoriv: u 2-kh t. [A complete collection of works]. Kyiv: Naukova dumka, 1973. T. 1. 532 p.; T. 2.576 p. [in Ukrainian].

7. Sukhomlynskyi, V. O. (1977). Vybrani tvory: u 5 t. [Selected Works]. T. 5. Kyiv: Rad. shkola. 639 p. [in Ukrainian].

8. Sukhomlynskyi, V. O. (1976). Vybrani tvory: u 5 t. [Selected Works]. T. 2. Kyiv: Rad. shkola. 521 p. [in Ukrainian].

9. Ushinskiy, K. D. (1990). Pedagogicheskie sochineniya $v 6 t$. [Pedagogical compositions in 6 tons]. T. 6. Pedagogika. 528 p. [in Russian].

Стаття надійшла до редакції 11.04.2018

\section{G5808NC2G58)

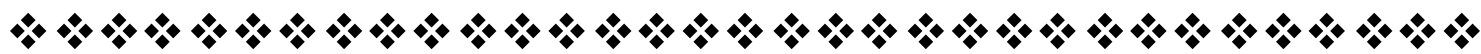

“Лрагніть не до успіху, а до йнностей, які він дає”. 